Religious Studies (2019) 55, 153-168 C) Cambridge University Press 2018. This is a work of the U.S. Government and is not subject to copyright protection in the United States.

doi:10.1017/S0034412518000446

\title{
Belief, credence, and faith
}

\author{
ELIZABETH JACKSON \\ Department of Philosophy, University of Notre Dame, 100 Malloy Hall, Notre Dame, IN \\ 46556, USA \\ e-mail: ejackso9@nd.edu
}

\begin{abstract}
In this article, I argue that faith's going beyond the evidence need not compromise faith's epistemic rationality. First, I explain how some of the recent literature on belief and credence points to a distinction between what I call B-evidence and C-evidence. Then, I apply this distinction to rational faith. I argue that if faith is more sensitive to $\mathrm{B}$-evidence than to $\mathrm{C}$-evidence, faith can go beyond the evidence and still be epistemically rational.
\end{abstract}

\section{Introduction}

In the Preface to the second edition of his Critique of Pure Reason, Kant famously reports, 'I have . . . found it necessary to deny knowledge, in order to make room for faith.' ${ }^{1}$ Similarly, Kierkegaard contrasts using his powers of reasoning with acting by virtue of the absurd, noting that 'The Absurd, or to act by virtue of the absurd, is to act upon faith.' ${ }^{2}$ Both of these authors suggest that faith is opposed to epistemically rational attitudes: Kierkegaard contrasts having faith with acting in accordance with reason, and Kant suggests that, at least in many cases, faith is incompatible with knowledge. ${ }^{3}$

These remarks hint at the famous problem of faith and reason. Specifically: it seems like epistemically rational attitudes are sensitive to evidence, including counterevidence. Yet it is essential to the nature of faith that it is resilient in the face of counterevidence. ${ }^{4}$ Some have argued that, for this reason, faith is simply irrational. For example, the New Atheists, such as Sam Harris and Richard Dawkins, suggest that faith closes one off to evidence and argument, and this leads to vices such as dogmatism and fundamentalism. ${ }^{5}$ Others, such as Kierkegaard, maintain that faith is epistemically irrational but nonetheless valuable. However, suppose that we don't want to say that faith is epistemically irrational. What other options do we have? 
In this article, I argue that faith that $p$ can be epistemically rational, even if it persists in light of significant evidence against $p$. To do so, I explore the relationship between rational belief and rational credence and relate it to rational faith. Specifically, I provide cases in which rational belief is insensitive to certain kinds of evidence. I argue that these cases point us to an important distinction between two types of evidence that I call B-evidence and C-evidence. Then, I apply this to rational faith, and argue that faith's being insensitive to certain kinds of evidence need not compromise faith's epistemic rationality. One key upshot of my view is that both rational belief that $p$ and rational faith that $p$ come apart from one's probabilistic support for $p .^{6}$ Overall, this is my basic argument:

(1) Rational belief is more sensitive to B-evidence than to C-evidence. [premise, supported by contemporary epistemology]

(2) If rational belief is more sensitive to B-evidence than to C-evidence, then faith is both (i) more sensitive to B-evidence than C-evidence and (ii) rational. [premise]

(3) Faith is both (i) more sensitive to B-evidence than C-evidence and (ii) rational. $[1,2]$

(4) One way for an attitude A to 'go beyond the evidence' is for A to be more sensitive to certain kinds of evidence than others. [premise]

(5) Thus, faith goes beyond the evidence and is rational. [3, 4]

This article proceeds as follows. In the next section, I defend premise 1 by summarizing some recent work in the literature on belief and credence. I explain a distinction between two kinds of evidence: B-evidence and C-evidence. In the following section, I apply this distinction to rational faith and argue for premises 2 and 4 . In the fourth section, I describe a few generalizations and upshots that emerge from my picture and conclude.

A few caveats before I begin: first, the focus of this article is normative, not descriptive. I am interested in rational faith (and rational belief and rational credence). Thus, I am not primarily concerned with providing a psychological description of these mental states, but how these states function for a rational agent.

What notion of rationality am I working with? Philosophers have noted that there are many strands of rationality; some have suggested there are as many as nine different kinds. ${ }^{7}$ First, I am interested in epistemic rationality. This brings my account of faith's rationality in contrast with other accounts in the literature, which have focused on the practical rationality of action-oriented faith. ${ }^{8} \mathrm{I}$ am interested in the epistemic rationality of faith qua mental state, rather than the practical rationality of faith qua commitment to act. Second, I focus on a specific strand of epistemic rationality that describes agents with the same cognitive powers as us who respond to evidence in an epistemically appropriate way. So, hold our 
mental processing power fixed; I am interested in questions about how we should respond to the evidence we encounter.

Finally, I am interested in propositional faith, or faith that some proposition is true. Many maintain this is not the only variety of faith. For example, Robert Audi (2011) contrasts propositional faith with attitudinal faith (faith in a person or entity) and volitional faith (a largely voluntary state of the will which disposes one to act certain ways). ${ }^{9}$ Insofar as these varieties of faith are not subject to epistemic evaluation, my arguments in this article are not intended to apply to them. While I do not want to rule out the wider applicability of my arguments, propositional faith is clearly epistemically evaluable, and thus I will focus there.

\section{Belief, credence, B-evidence, and C-evidence}

Belief is a familiar doxastic attitude; belief that $p$ is taking $p$ to be the case or regarding $p$ as true. ${ }^{10}$ Yet we are more confident in some of our beliefs than in others. I believe both that $1+1=2$ and that my car is parked outside, but I am more confident in the former belief than in the latter belief. For this reason, epistemologists have appealed to another doxastic attitude they call credences. Credences are, in many ways, similar to degrees of confidence. Credences are much more fine-grained than beliefs and are often given a value on the $[0,1]$ interval. For example, I have a credence of 1 that $1+1=2$, a 0.99 credence my car is parked outside, and a 0.5 credence that a fair two-sided coin will land heads.

\section{Rational high credence without rational belief}

A topic of recent interest to epistemologists involves the ways that belief and credence respond to evidence. In many cases where we gain significant evidence for some proposition $p$, we ought to both believe that $p$ and have a high credence that $p$. I perceive a coffee cup on the table, so I both believe and have a high credence that it is on the table. I hear from a reliable friend that the talk is at 3:00 today, so I believe and have a high credence the talk is at 3:00. However, not all cases are like these. Sometimes, one's evidence generates a rational high credence but not rational belief. Three examples of these cases are as follows:

Lottery propositions: Suppose I have a lottery ticket that is part of a fair lottery of 100 tickets. I ought to have a high credence my ticket will lose (0.99). However, I ought not to believe my ticket will lose.

There are at least two arguments that I ought not to believe my ticket will lose. First, if I can rationally believe my ticket will lose, and rational belief is closed under conjunction, then I rationally believe the large conjunction that <ticket 1 will lose and ticket 2 will lose and ticket 3 will lose . . . >. However, I also believe the negation of this conjunction, since one ticket will win. Assuming it is irrational to have contradictory beliefs, I ought to reject one of the above 
assumptions, and a natural assumption to reject is that I ought not to believe my ticket is a loser. ${ }^{11}$

The second is as follows: I cannot know my lottery ticket lost. Knowledge is the norm of belief. Therefore, I ought not to believe my lottery ticket lost. ${ }^{12}$ Thus, it is plausible that I ought to have a high credence in but not believe lottery propositions; my evidence that I lost the lottery is credence-justifying but not beliefjustifying. ${ }^{13}$

A second example of evidence that is credence-generating but not belief-generating is from Lara Buchak (2014), as follows:

Naked statistical evidence: Suppose I am a juror trying to figure out which bus company hit some victim, and $90 \%$ of the buses in town are operated by the Blue Bus Company. I ought not to believe that the Blue Bus Company hit the victim on this basis, even though the evidence justifies raising my credence (potentially even significantly) that they did it. ${ }^{14}$

Not only does Buchak think this is the intuitive reading of the cases, but it is also justified by legal norms. For example, it would be impermissible to convict the Blue Bus Company based on statistical evidence alone. ${ }^{15}$

A final case is from Martin Smith (2010), adapted from Dana Nelkin (2000):

Non-normic support: Suppose I have set up my computer such that the background colour is determined by a random number generator, and 1 / $1,000,000$ times it is red; otherwise it is blue. One day I turn on my computer and go into the next room to do something else. I ought to have a very high credence (o.999999) that my computer's background is blue, but I ought not believe it is blue. ${ }^{16}$

Smith notes, however, that if his friend Bruce wanders in and sees a blue background on the computer, it seems like Bruce can justifiedly believe the background is blue. Smith uses the term 'normic support' to describe the kind of evidential support Bruce has; Smith merely has 'non-normic' support for this proposition. Smith maintains that what differentiates normic and non-normic support involves when evidentially supported but false beliefs cry out for explanation. Specifically, when we have normic support for a belief and the belief turns out to be false, we seek some kind of explanation for why it is false. This is why, if Bruce's belief that the screen was blue is false, we would want to know why - was he hallucinating, or suddenly struck with colour blindness? However, when we have evidence that frequently but not normally supports some proposition, no such explanation is sought. If Smith's belief were false, we would not seek such an explanation. ${ }^{17}$ Thus, when we have mere non-normic support for $p$, we are justified in having a high credence, but not believing that $p$.

In all three of these cases, there is evidence that is credence-generating but not belief-generating. These cases suggest that rational belief is not merely a matter of 
probabilistic support; whatever justifies belief isn't merely a high probability that the believed proposition is true. ${ }^{18}$

Another interesting feature of these cases is that there are close versions of the cases that seem to generate both rational belief and rational high credence. In the first case, when I hear the winning numbers announced and realize they are not my numbers, I rationally believe my ticket lost. In the second case, when I hear a reliable eyewitness testify that the Blue Bus Company is guilty, I rationally believe the Blue Bus Company is guilty. In the third case, Bruce rationally believes the background is blue based on his perceptual evidence.

Why might this be? What kind of evidence affects our beliefs and credences, and what kind of evidence affects only our credences? I will suggest a distinction between two types of evidence that makes sense of the above cases. ${ }^{19}$

\section{B-evidence and C-evidence}

What is the difference between evidence that is credence-generating and evidence that is belief-generating? I submit that the answer has to do with the following distinction:

B-evidence: Evidence for $p$ that does not make salient the possibility that not- $p$.

$C$-evidence: Evidence for $p$ that makes salient the possibility that not- $p .^{20}$

A salient possibility is a possibility to which an agent is rationally paying attention. ${ }^{21}$ To illustrate this distinction further, consider some examples. A common way to get B-evidence is to get evidence that $p$ is true without qualification, such as when someone asserts $p$. C-evidence for $p$ includes statistical evidence for $p$, and also includes evidence for $p$ that is hedged or qualified in some way, e.g., 'P is decently likely, but I'm honestly not sure.' Given this distinction, we can explain the cases above in the following way:

(1) Rational belief is more sensitive to B-evidence than to C-evidence.

Note that (1) is the first premise of our argument. Since the word 'sensitive' is somewhat vague, we can clarify (1) in the following way:

(1.1) It is usually irrational to believe that $p$ on the basis of mere C-evidence for $p .^{22}$

(1.2) It is usually rational to believe that $p$ on the basis of (good) B-evidence for $p$.

\section{Explaining the Cases}

(1.1) and (1.2) explain why I ought not to believe lottery propositions, propositions for which I have only statistical evidence, and propositions with mere 
non-normic support. It also explains why I can believe the relevant propositions in the alternative versions of the cases mentioned above.

In the lottery case, I have evidence that directs my attention to the possibility that I might win. I know that one ticket is going to win, and winners are celebrated and given lots of attention. When a lottery ticket is in my hand, my evidence calls me to pay attention to the possibility that I might just be the winner, so my evidence is C-evidence. Since rational belief is not based on C-evidence alone, I ought not to believe I will lose. However, if I am given B-evidence for the proposition that I lost, I can rationally believe I lost; this happens when I hear the winning numbers (that aren't on my ticket). Thus, (1.1) and (1.2) can explain lottery cases.

In the statistical evidence case, the fact that 90 per cent of the buses in a town are run by the Blue Bus Company is merely C-evidence that the Blue Bus Company is guilty; it makes salient the possibility that another bus company might be responsible. Thus, I ought not to believe the Blue Bus Company is guilty or convict them on this basis. However, when a reliable eyewitness testifies that they saw one of the Blue Bus Company's buses hit the pedestrian, I have B-evidence that the Blue Bus Company is responsible, and ought to both believe they did it and (in normal circumstances) convict them on this basis.

In the non-normic support case, the fact that Smith's computer background is determined by a random number generator that makes it blue 999,999/ $1,000,000$ times is mere C-evidence that the background is blue. However, upon seeing the blue background, Bruce has B-evidence that the background is blue.

Thus, I maintain that the distinction between B-evidence and C-evidence plays an important role in the relationship between rational belief, rational credence, and evidence. However, while I have argued that my account can explain the above cases well, I have not considered other accounts that may also explain these cases. Thus, while I prefer my suggested account, I also think that the distinction between B-evidence and C-evidence could be spelled out in a more ecumenical way. ${ }^{23}$ For example, consider the following chart:

B-evidence C-evidence

- Many cases of testimony and perception, especially e.g. flat-out assertions, clear perceptions of medium-sized objects

- Evidence for $p$ that would require an explanation if $p$ turned out to be false

- Evidence for $p$ that doesn't make salient the possibility of not- $p$

- Evidence for lottery propositions

- Statistical evidence

- Hedged assertions

- Evidence for $p$ that would not require an explanation if $p$ turned out to be false

- Evidence for $p$ that makes salient the possibility of not- $p$ 
One could define B-evidence and C-evidence as the items listed above (or a subset of them); this would be less controversial, explain the cases, and apply equally well to the problem of faith and reason. I will proceed on the assumption that my preferred account is true, but it is worth noting that many of the same moves can be made while employing a less controversial version of the distinction.

Now, I will argue that the distinction between B-evidence and C-evidence is important for understanding rational faith.

\section{Faith, B-evidence, and C-evidence}

\section{A defence of premise 2}

In this section, I defend the second premise of my argument:

(2) If rational belief is more sensitive to B-evidence than to C-evidence, then faith is both (i) more sensitive to B-evidence than C-evidence and (ii) rational.

The idea behind (2) is that there is rational parity between faith and belief; if belief can be more sensitive to some kinds of evidence than others and nonetheless rational, then it seems as though rational faith can be similarly sensitive to some kinds of evidence more than others.

To further defend and explain (2), I will give four cases of faith that are structurally similar to the lottery, statistical, and non-normic cases in the previous section. If rational belief is more sensitive to $\mathrm{B}$-evidence than $\mathrm{C}$-evidence in these cases, then structurally similar cases of faith can be rational as well. Or so I will argue.

Case 1: Sally knows (let's say) that $90 \%$ of philosophers keep secrets. Sally is considering telling Rebecca, her new philosopher friend, a secret, but since Sally just met her, Sally doesn't have faith that she is trustworthy. Sally doesn't have faith that Rebecca will keep the secret just based on the statistic about philosophers.

Case 1 is structurally similar to the case of naked statistical evidence case. I cannot believe that the Blue Bus Company is guilty simply because they operate 90 per cent of the buses in town, and Sally cannot have faith that Rebecca is trustworthy just because 90 per cent of philosophers keep secrets. However, consider a version of the case on which Sally receives B-evidence that Rebecca is trustworthy, e.g. Sally receives testimony from some of Rebecca's friends that Rebecca is honest and dependable, or Sally gets to know Rebecca and perceives these virtues in her. Then, Sally can rationally have faith Rebecca will keep the secret. This second version of the case parallels the case where I have testimonial evidence rather than merely statistical evidence that the Blue Bus Company is guilty. The 
testimony (B-evidence), but not the mere statistic (C-evidence), justifies rational belief and rational faith.

Case 2: John does not have faith that God exists. He reads online about the fine-tuning argument, which purports to show that facts about the physical conditions required for life make theism much more probable than atheism. John finds the argument convincing, and raises his credence that God exists; however, the evidence from the fine-tuning argument does not produce in John faith that God exists.

As in Case 1, Case 2 parallels the cases above in which C-evidence generates a high credence that $p$ but not belief that $p$. The mere fact that the fine-tuning argument makes theism probable does not justify John's having faith that God exists. However, suppose John hears his friend Sarah's testimony. Sarah describes her personal relationship with God and ways that God has helped her and cared for her. After hearing Sarah's story, John has faith that God exists. The B-evidence that God exists from Sarah justifies John's faith that God exists.

Cases 1 and 2 directly parallel the cases of rational belief above, in which I have a high credence in $p$ but do not believe $p$. However, the distinction between B-evidence and C-evidence also enables the generation of cases with the opposite structure: belief that $p$ is rational, even though I get evidence that (even significantly) lowers my credence that $p$. For example, you might have an eyewitness testify that the Green Bus Company is guilty, and then learn that the Green Bus Company only operates 10 per cent of the buses in town. Similarly, I might perceive the computer's red background, and then learn that the background is determined by a random number generator which makes this extremely unlikely. In both cases, the $\mathrm{C}$-evidence against the proposition requires me to lower my credence in $p$, but I can nonetheless still rationally believe $p$. These cases are especially interesting when applied to faith, because they are cases in which epistemically rational faith can remain steadfast in light of counterevidence. For example:

Case 3: Billy is happily engaged and will be married soon. He has good evidence that he and his spouse are uniquely sincere and serious. Based on their backgrounds and personalities, he has reason to think that their level of commitment is stronger than that of many other couples. Billy has faith that he and his future spouse will not get divorced. Then, Billy learns that half of all marriages end in divorce. Learning this statistic does not affect his faith that they will not get divorced.

In Case 3, Billy has good B-evidence that he and his spouse won't get divorced. The statistic (C-evidence) that Billy learns ought to count against this to some degree, and Billy should lower his credence. Nonetheless, it still seems rational for Billy to 
continue to have faith that he and his spouse will remain committed. Thus, Billy's faith is rational, even upon his receiving the statistical counterevidence.

Consider a final case:

Case 4: Susan, a Christian, has had many personal experiences of God through prayer and liturgy. She has faith that an all-good God exists (call this proposition G). She reads an article that presents the evidential problem of evil; it uses examples of evil in the world to (purportedly) lower the probability of G. Susan continues to have faith that G despite her new evidence that lowers the probability of G. ${ }^{24}$

In Case 4, assume that Susan's religious experiences are evidentially significant. ${ }^{25}$ Then, Susan has good B-evidence for G. Susan then gets evidence that lowers the probability of G. Getting this evidence might require Susan to lower her credence in $\mathrm{G}$, but in virtue of the fact that it is C-evidence, it does not flat out establish that the existence of an all-good God is impossible. Since Susan's religious experiences are quite evidentially significant, Susan can nonetheless rationally continue to have faith that $\mathrm{G}$.

It is worth noting, however, that while rational faith that $p$ is consistent with $\mathrm{C}$ evidence against $p$, it isn't consistent with any amount of $\mathrm{C}$-evidence against $p$. Presumably, if the C-evidence were significant enough to substantially lower Susan's credence (say, well below 0.5), continuing to have faith may no longer be rational. ${ }^{26}$ Uncontroversially, rational faith's steadfastness will depend on the weight of the evidence for and against the proposition of faith. However, the point here is that the type of evidence also matters; rational faith is not a mere matter of probabilistic support. Rational faith, like rational belief, can remain steadfast in cases where it otherwise would not, if it is supported by good $\mathrm{B}$-evidence and has merely or mainly C-evidence going against it.

Thus, I maintain that if rational belief is more sensitive to B-evidence than to $\mathrm{C}$-evidence, then rational faith is more sensitive to $\mathrm{B}$-evidence than $\mathrm{C}$-evidence as well. The cases that support this thesis about belief can be extended to cases of faith. In the same way that rational belief is not merely a matter of probabilistic support, rational faith is also not merely about probabilistic support.

Another way of putting this point is that the Lockean view of rational belief and rational faith is false. The Lockean Thesis, usually stated as a thesis about belief, claims that $\mathrm{S}$ 's belief that $p$ is rational iff it is rational for $\mathrm{S}$ to have a sufficiently high credence that $p .{ }^{27}$ One could also hold a Lockean view of rational faith, i.e. $\mathrm{S}$ 's faith that $p$ is rational iff it is rational for $\mathrm{S}$ to have a sufficiently high credence that $p$. I have argued that both of these versions of the Lockean Thesis are false. One can have a high credence in $p$ but not have rational faith that $p$, and rational faith that $p$ is consistent with a rational low credence in $p$.

We now have a defence of premises (1) and (2), and therefore our first conclusion: 
(3) Faith is both (i) more sensitive to B-evidence than C-evidence and (ii) rational.

We can fill out this account as we did with rational belief, with a similar understanding of sensitivity. That is:

(3.1) It is usually irrational to have (or lose) faith that $p$ on the basis of mere C-evidence for $p$,

and

(3.2) It is usually rational to have faith that $p$ on the basis of (good) B-evidence for $p$.

\section{A defence of premise 4}

In this section, I defend premise (4) of my argument:

(4) One way for an attitude A to 'go beyond the evidence' is for A to be more sensitive to certain kinds of evidence than others.

'Going beyond the evidence' is, admittedly, a phrase that is both metaphorical and somewhat vague. ${ }^{28}$ However, I maintain that at least one way that S's attitude A might go beyond the evidence is that A is insensitive to certain parts of S's body of evidence. A paradigm example of an attitude that does not go beyond the evidence is rational credence; S's credence, if rational, tightly tracks the amount of evidence $S$ has for or against some proposition. Nonetheless, I have argued that certain attitudes do not perfectly track evidence in this way, even though they are rational. One may have a lot of evidential or probabilistic support for some proposition and nonetheless fail to have justification to believe it or have faith that it is true. Additionally, one might have evidence that justifies faith/belief, and be justified in maintaining these attitudes even in light of counterevidence that lowers (even significantly) the probability of the proposition in question. Once one sees that probabilistic support comes apart from what justifies faith/ belief, it becomes clear that there is a sense in which both attitudes go beyond the evidence. They remain steadfast as C-evidence lowers and raises the probability of the relevant proposition.

Here, an objector might worry that, even if I have pointed out an interesting sense in which rational faith goes beyond the evidence, my account also entails that rational belief goes beyond the evidence. But that's a somewhat odd suggestion; prima facie, belief does not seem to be an attitude that goes beyond the evidence. My response is as follows: if faith entails belief, this is not surprising. If faith does not entail belief, then faith can go beyond the evidence in a way that belief does not.

Suppose first that faith entails belief. Most who have defended the view that faith entails belief argue for a 'belief-plus' view of faith, on which faith is partially 
constituted by belief. ${ }^{29}$ On most versions of the 'belief-plus' view, faith is a subset of our beliefs that meet certain other conditions, e.g. the ones towards which we have an affective attitude. If faith just is a kind of believing, and faith goes beyond the evidence, then at least a subset of one's beliefs does as well. Of course, it is a leap from this to say that all beliefs go beyond the evidence, but this model makes that conclusion much less of a bullet to bite. So, on the 'belief plus' model, the conclusion that belief goes beyond the evidence is not surprising.

Suppose instead that faith does not entail belief. ${ }^{30}$ Then, faith can go beyond the evidence in a way that belief does not, as faith may be even more steadfast in light of counterevidence than belief. Defenders of the view that faith doesn't entail belief have argued that this can give faith a unique steadfastness in the face of counterevidence; one might receive counterevidence such that they can no longer rationally believe $p$, but this need not rule out rational faith that $p \cdot{ }^{31}$ For example, suppose I get B-evidence for a proposition $p$ that justifies both faith and belief that $p$. Then, I get significant $\mathrm{C}$-evidence against $p$, such that my credence that $p$ goes well below 0.5. Assuming that rational credence well below 0.5 that $p$ is inconsistent with rational belief that $p$ (lower the credence as you like), I can no longer rationally believe that $p$. However, this may not rule out rational faith, if faith does not entail belief. As Dan Howard Snyder (2013) points out, I may have other attitudes towards $p$ that count toward faith that $p$ : I accept that $p, \mathrm{I}$ believe $p$ is not especially improbable, I believe $p$ is more likely than alternatives, I desire that $p$, etc. Thus, on this view of faith, faith that $p$ can be steadfast in light of significant evidence against $p$ - potentially even more steadfast than belief. There may still be some sense in which belief goes beyond the evidence, but faith does so in a more drastic and significant way.

Thus, I conclude that one way an attitude goes beyond the evidence is for that attitude to be more sensitive to some parts of a body of evidence than other parts. While this might entail that rational belief goes beyond the evidence, this is either not surprising or occurs in a much more modest way than in the case of rational faith.

\section{Upshots and conclusion}

There are several noteworthy features of faith that my view captures. First, this picture of faith explains the personal aspect of faith. Many paradigm examples of B-evidence are testimonial. ${ }^{32}$ Faith's sensitivity to testimonial B-evidence more than C-evidence explains why community and personal interaction is so important to faith, and faith is a virtue and a vital characteristic of strong communities. Further, a clear perception that $p$ is also a paradigm example of B-evidence for $p$, and this can explain the idea that perception and experience of God can lead to rational religious faith. ${ }^{33}$ Thus, my view explains why having a tight-knit religious community, a close relationship with God, and religious experiences are important aspects of religious faith. 
Second, it is notable that many common objections to religious faith are based on C-evidence. For example, the evidential problem of evil purportedly lowers the probability of the existence of an all-good God, but is not B-evidence against God's existence. Some arguments against the existence of miracles are also plausibly construed as C-evidence, insofar as they purport to lower the probability of a miracle's occurring, given the regular laws of nature we observe. Further, direct experiences of God's non-existence that would count as B-evidence for atheism seem quite rare, if they occur at all. ${ }^{34}$

Third, my account provides a picture that divides our epistemic lives into two camps, putting credences, C-evidence, and statistical evidence in one epistemic group, and belief, faith, and B-evidence in another epistemic group. One suggestion is that we have two different 'epistemic toolboxes', and which toolbox we use depends on both our epistemic and practical situation. ${ }^{35}$ This further supports the idea that belief and faith have a similar function, and this role is different from the role of credence and C-evidence. ${ }^{36}$

Finally, some, such as Jacob Ross and Mark Schroeder, have suggested that one reason we have beliefs is because of our non-ideal cognitive state. ${ }^{37}$ While an ideal agent might reason using only credences, beliefs are necessary because we do not have the cognitive power to assign probabilities to every relevant proposition and do the (large and complex) resulting calculation. ${ }^{38}$ (Recall that the notion of rationality I am concerned with is how we ought to respond to evidence, given our limited cognitive faculties.) Ross and Schroeder's suggestion is, of course, controversial, but it is potentially interesting when combined with my view of faith. One might think faith is similar to belief in that it is a result our non-ideal cognitive state. If we could access and perfectly assess all the relevant evidence for and against a proposition, faith might not be necessary. There is some evidence from religious texts that faith is necessary because of our cognitive limitations: we 'live by faith and not by sight', 39 and 'now we see things imperfectly, like puzzling reflections in a mirror, but then we will see everything with perfect clarity'.$^{40} \mathrm{I}$ commit myself to a mere conditional claim here: if beliefs are a result of our nonideal cognitive state, and faith and belief function similarly with respect to evidence, it makes sense that faith would also be a result of our non-ideal cognitive state.

In conclusion, I have argued that faith can both be rational and can also 'go beyond the evidence'. I have done so by arguing that rational belief is more sensitive to some parts of a body of evidence than other parts, and that the same can hold true for faith without compromising its rationality. I conclude that both rational faith and rational belief are more sensitive to B-evidence than to C-evidence. That this is true of rational belief explains why evidence that a ticket will lose the lottery and mere statistical evidence justify high credence but not belief. That this is true of faith, I have argued, provides an account of how faith can be both rational and go beyond the evidence. My hope is that my arguments in this article can be a part of the solution to the problem of faith and reason. ${ }^{41}$ 


\section{References}

Alston, William (1991) Perceiving God (Ithaca NY: Cornell University Press).

Alston, William (1996) 'Belief, acceptance, and religious faith', in Jeff Jordan \& Daniel Howard-Snyder (eds) Faith, Freedom, and Rationality (Lanham, MD: Rowman \& Littlefield), 3-27.

Audi, Roвert (1991) 'Faith, belief, and rationality', Philosophical Perspectives, 5, 213-239.

Audi, Robert (2011) Rationality and Religious Commitment (Oxford: Oxford University Press).

Blome-Tillman, Michael (2015). 'Sensitivity, causality, and statistical evidence in courts of law', Thought, 4, 102-112.

Blome-Tillman, Michael (2017) “"More likely than not” - knowledge first and the role of statistical evidence in courts of law', in Adam Carter, Emma Gordon, \& Benjamin Jarvis (eds) Knowledge First (Oxford: Oxford University Press), 278-292.

BuсHAк, LARA (2012) 'Can it be rational to have faith?', in Jake Chandler \& Victoria Harrison (eds) Probability and Philosophy of Religion (Oxford: Oxford University Press), 225-247.

BuchaK, LARA (2014) 'Belief, credence, and norms', Philosophical Studies, 169, 285-311.

BuchaK, LARA (2017) 'Reason and faith', in William J. Abraham \& Frederick D. Aquino (eds) The Oxford Handbook of the Epistemology of Theology (Oxford: Oxford University Press), 46-63.

Christensen, David (2004) Putting Logic in its Place (Oxford: Oxford University Press).

Cohen, Jonathan (1977) The Probable and the Provable (Oxford: Oxford University Press).

Cohen, Jonathan (2010) 'Rationality', in J. Dancy, E. Sosa, \& M. Steup (eds) A Companion to Epistemology (Singapore: Wiley-Blackwell), 663-668.

Coluins, John (2006) 'Lotteries and the close shave principle', in Stephen Hetherington (ed.) Aspects of Knowing: Epistemological Essays (Amsterdam: Elsevier Science), 83-96.

Colyvan, Mark, Regan, Helen, \& Ferson, Scott (2001) 'Is it a crime to belong to a reference class?', Journal of Political Philosophy, 9, 168-181.

Dawkins, Richard (2006) The God Delusion (Boston MA: Mariner Books).

Dorst, KeVIn (2017) 'Lockeans maximize expected accuracy', Mind.

Enoch, DAvid, Spectre, Levi, \& Fisher, TAlia (2012) 'Statistical evidence, sensitivity, and the legal value of knowledge', Philosophy and Public Affairs, 40, 197-244.

Fitelson, Branden \& Shear, Ted (2018) 'Two approaches to belief revision', Erkenntnis, 1-32.

Foley, Richard (1993) Working without a Net (Oxford: Oxford University Press).

Friedman, Jane (2013) 'Rational agnosticism and degrees of belief', Oxford Studies in Epistemology, 4, 57-82.

Fumerton, Richard (2004) 'Epistemic probability', Philosophical Perspectives, 14, 149-164.

GigERENZER, GERD \& GoLDSTEIN, DANIEL (1996) 'Reasoning the fast and frugal way: models of bounded rationality', Psychological Review, 103, 650-669.

Gigerenzer, Gerd, Todd, Peter, \& ABC Research Group (1999) Simple Heuristics that Make Us Smart (Oxford: Oxford University Press).

Goldstick, D. (2000) 'Three epistemic senses of probability', Philosophical Studies, 101, 59-76.

Harris, Samuel (2004) The End of Faith (New York: W. W. Norton).

Horgan, Terrance (2017) 'Troubles for Bayesian formal epistemology', Res Philosophica, 94, 233-255.

Howard-SNyder, Daniel (2013) 'Propositional faith: what it is and what it is not', American Philosophical Quarterly, 50, 357-372.

Howard-Snyder, Daniel (2016) 'Does faith entail belief?', Faith and Philosophy, 33, 142-162.

Howard-SNyder, Daniel (2017) 'Markan faith', International Journal for Philosophy of Religion, 81, 31-60.

JACKSON, ElizABETH, (MS) 'Belief, credence, and evidence'.

Kant, Immanuel (1787/1933) Critique of Pure Reason, 2nd edn, Norman Kemp Smith (tr.) (London: Macmillan). Kaplan, Mark (1996) Decision Theory as Philosophy (Cambridge: Cambridge University Press).

Kelp, Снristopн (2017) 'Lotteries and justification', Synthese, 194, 1233-1244.

KierkegaARd, Søren (1849) Journals (Princeton NJ: Princeton University Press).

Kvanvig, Jonathan (2013) 'Affective theism and people of faith', Midwest Studies in Philosophy, 37, 109-128.

Kvanvig, Jonathan (2016) The idea of faith as trust: lessons in noncognitivist approaches to faith', in Michael Bergmann \& Jeffrey Brower (eds) Reason and Faith: Themes from Richard Swinburne (Oxford: Oxford University Press), 4-26.

Kyвurg, H. E. (1961) Probability and the Logic of Rational Belief (Middleton CT: Wesleyan University Press). Lewis, DAvid (1996) 'Elusive knowledge', Australasian Journal of Philosophy, 74, 549-567. 
Lin, Hanti \& Kelly, Kevin (2013) 'Propositional reasoning that tracks probabilistic reasoning', Journal of Philosophical Logic, 41, 957-981.

LOCKE, Dustin (2014) 'The decision theoretic Lockean thesis', Inquiry, 57, 28-54.

Maher, Patrick (1993) Betting on Theories (Cambridge: Cambridge University Press).

Malcolm, Finlay \& Scott, Michael (2016) 'Faith, belief, and fictionalism', Pacific Philosophical Quarterly, 98, 257-274.

McKaughan, Daniel (2016) 'Action-centered faith, doubt, and rationality', Journal of Philosophical Research, 41, 71-90. Issue Supplement: Selected Papers in Honor of William P. Alston.

McKaughan, Daniel (2017) 'On the value of faith and faithfulness', International Journal for Philosophy of Religion, 81, 7-29.

Moss, SARAh (2018) Probabilistic Knowledge (Oxford: Oxford University Press).

MugG, Joshua (2016) 'In defence of the belief-plus model of faith', European Journal for Philosophy of Religion, 8, 201-219.

Nelkin, Dana (2000) 'The lottery paradox, knowledge, and rationality', The Philosophical Review, 109, 373-409.

Pasnau, Robert, (MS) 'Belief in a fallen world'.

PAYNE, John W. \& Bettman, James R. (2004) 'Walking with the scarecrow: the information-processing approach to decision research', in D. Koehler \& N. Harvey (eds) The Blackwell Handbook of Judgment and Decision Making (Oxford: Blackwell), 110-131.

Payne, John W., Bettman, James R., \& Johnson, Eric J. (1993) The Adaptive Decision Maker (Cambridge: Cambridge University Press).

Plantinga, Alvin (1993) Warrant and Proper Function (Oxford: Oxford University Press).

Ross, JАCOB \& SCHRODER, MARK (2014) 'Belief, credence, and pragmatic encroachment', Philosophy and Phenomenological Research, 88, 259-288.

Schauer, Frederick (2003) Profiles, Probabilities, and Stereotypes (Cambridge MA: Belknap Press).

Schwitzgebel, Eric (2015) 'Belief', Stanford Encyclopedia of Philosophy, <http://plato.stanford.edu/entries/ belief/ >

Sмith, Martin (2010) 'What else justification could be', Nous, 44, 10-31.

Sмith, Martin (2016) Between Probability and Certainty: What Justifies Belief (Oxford: Oxford University Press).

Staffel, Julia (2015) 'Beliefs, buses, and lotteries: why rational belief can't be stably high credence', in Philosophical Studies, 173, 1721-1734.

StafFel, Julia (2017) 'Accuracy for believers', Episteme, 14, 39-48.

StuRgeon, Scott (2008) 'Reason and the grain of belief', Nous, 42, 139-165.

TANG, Weng Hong (2015) 'Belief and cognitive limitations', Philosophical Studies, 172, 249-260.

Thomson, Judith (1986) 'Liability and individualized evidence', Law and Contemporary Problems, 49, 199-219.

Turri, John (2008) 'Practical and epistemic justification in Alston's Perceiving God', Faith and Philosophy, 25, 290-299.

Weisberg, Jonathan (forthcoming) 'Belief in psyontology', Philosopher's Imprint, <http://jonathanweisberg.org/ pdf/Psyontology.pdf>.

West, Ryan \& Pelser, Adam C. (2015) 'Perceiving God through natural beauty', Faith and Philosophy, 32, 293-312.

Williamson, Тімотну (2000) Knowledge and its Limits (Oxford: Oxford University Press).

\section{Notes}

1. Kant (1787/1933), 29.

2. Kierkegaard (1849).

3. I acknowledge there are delicate interpretative issues here, and I do not claim to give a full picture of Kant's or Kierkegaard's views on faith.

4. See Buchak (2012), 229, and Buchak (2017).

5. Dawkins (2006), 320; Harris (2004), 48.

6. When I talk about probabilistic support in this article, the type of probability I have in mind is epistemic probability, or the probability of some proposition given one's evidence. For more on epistemic probability, see Goldstick (2000) and Fumerton (2004).

7. See Cohen (2010), 663, and Plantinga (1993), vii-viii. 
8. See e.g. Buchak (2012) and McKaughan (2016).

9. Audi (2011), pt II. Audi actually distinguishes between seven kinds of faith, but these are the main three.

10. Schwitzgebel (2015).

11. See Staffel (2015). For other discussions of the lottery paradox, especially with respect to the relationship between belief and credence, see Kyburg (1961); Foley (1993), ch. 4; Nelkin (2000); Christensen (2004), ch. 2; Collins (2006); Sturgeon (2008); Kelp (2017).

12. Staffel (2015). See Williamson (2000), 255.

13. See Kelp (2017) for an additional argument that it is irrational to believe lottery propositions. Horgan (2017) also maintains one ought not to believe lottery propositions: 'outright belief that one's lottery ticket will lose does not seem epistemically justified, no matter how high are the odds against winning' (ibid., 242).

14. Buchak (2014). The case originates in Schauer (2003). See also Staffel (2015).

15. See Cohen (1977), Thomson (1986), Colyvan et al. (2001), Enoch et al. (2012), Blome-Tillmann (2015), and Idem (2017).

16. Smith (2010), 13-14.

17. Ibid., 15-19.

18. See Smith (2010), Idem (2016). It is controversial whether maximal probabilistic support (i.e. to degree 1) justifies rational belief. Prima facie, it might seem that rational credence 1 that $p$ entails rational belief that $p$, but some, e.g. Moss (2018), have suggested there are cases of rational credence 1 without rational belief (33).

19. One might think that the answer is that rational agents do not form beliefs on the basis of statistical evidence alone. While this suggestion gets many of the cases right, I argue that my account is superior in Jackson (MS).

20. Thanks to Blake Roeber. See Ross \& Schroder (2014), 18. One might wonder in what sense B-evidence and C-evidence are different kinds of evidence. I remain agnostic on whether this is a metaphysically robust, joint-carving distinction, but I do think that it has epistemic significance. This account of the difference between belief-generating and credence-generating evidence is further developed in Jackson (MS).

21. See Lewis (1996), 559. See especially his 'Rule of Attention'. For more on the role of salience in B-evidence and C-evidence, see Jackson (MS).

22. (1.1) is qualified because there may be exceptions to it, such as the following: suppose I know that the bus arrives on time in $98 \%$ of cases, and on that basis, I believe it will arrive on time today. It is not obvious that my belief is irrational, even though it has merely C-evidence in its favour. Sometimes, a low-stakes belief with extremely good statistical evidence going for it seems at least rationally permissible, and (1.1) makes room for that. For related cases see Pasnau (MS). Thanks to an anonymous referee.

23. Thanks to an anonymous referee.

24. Thanks to an anonymous referee.

25. For a defence of the claim that religious experience can be evidentially significant, see Alston (1991).

26. At least, continuing to have propositional faith may no longer be rational. There may be other types of faith (e.g. acts of faith) that could be rational in this situation.

27. See Foley (1993), 140-141. For defences of the Lockean Thesis, see ibid., ch. 4; Christensen (2004); Sturgeon (2008); Lin \& Kelly (2013); Locke (2014); Dorst (2017); Fitelson \& Shear (2018). For arguments against the Lockean Thesis, see Smith (2010), Friedman (2013), Buchak (2014), Staffel (2015), Smith (2016), Kelp (2017).

28. See Buchak (2012), 229-232, for more on faith and going beyond the evidence.

29. See Mugg (2016) and Malcolm \& Scott (2016) for defences of the belief-plus model.

30. See Audi (1991), Alston (1996), Howard-Snyder (2013), Kvanvig (2013), Howard-Snyder (2016), Kvanvig (2016), McKaughan (2016), Howard-Snyder (2017), and McKaughan (2017) for defences of the claim that faith does not entail belief. One might worry that this claim is in tension with things I've argued above; for example, why do we need to give so much attention to rational belief for an understanding of rational faith, if faith does not entail belief? In response, note that all I have argued above is that faith and belief share a certain necessary condition that involves sensitivity to evidence. This need not rule out the idea that it is possible to have faith that $p$ without believing that $p$; the attitudes can otherwise come apart in many ways. Thanks to an anonymous referee.

31. See, e.g. Audi (1991), Howard-Snyder (2013), Idem (2016), McKaughan (2016).

32. Especially when the content of the testimony is not hedged or statistical. However, this might depend on one's view of testimony. On certain reductionist views of testimony, it might be less straightforward that 
testimony is generally B-evidence. For example, if what grounds a testimonial belief is e.g. ' $\mathrm{S}$ asserted $p$ and S is statistically reliable', testimonial evidence begins to look like C-evidence. Thanks to an anonymous referee.

33. See Alston (1991), Turri (2008), West \& Pelser (2015).

34. Thanks to an anonymous referee.

35. This is also supported by the 'adaptive toolbox' model in psychology. See Payne et al. (1993), Gigerenzer \& Goldstein (1996), Gigerenzer et al. (1999), Payne \& Bettman (2004).

36. See Buchak (2014), Weisberg (forthcoming).

37. See Foley (1993), ch. 4; Ross \& Schroeder (2014); Tang (2015); Weisberg (forthcoming).

38. Ross \& Schroeder (2014), 285-286. See also Kaplan (1996); Maher (1993), ch. 6; Staffel (2017).

39. 2 Cor. 5:7 (English Standard Version).

40. 1 Cor. 13:12 (New Living Translation).

41. Thanks to Andrew Moon, Blake Roeber, Fritz Warfield, John Keller, Lara Buchak, Ben Lennertz, Alan Hajek, Jeff Tolly, Ting Lau, Anne Jeffery, Nevin Climenhaga, Dustin Crummett, Ross Jensen, Rebecca Chan, Anne Jeffrey, Julia Staffel, Robert Audi, Daniel Nolan, Andy Rogers, Ian Huyett, Miriam Hickman, Blake Roeber's Doxastic Voluntarism seminar, the Notre Dame epistemology reading group, audiences at the 2016 St. Thomas Summer Seminar, 2016 Society for Christian Philosophers Eastern Regional Meeting, the 2016 Indiana Philosophical Association, the 2017 Kaufman Interfaith Institute Workshop, and several anonymous referees for helpful comments and suggestions that improved this article in many ways. 